\title{
TROUBLING IDEALS: REBECCA HARDING DAVIS AND THE CONSEQUENCES OF INDUSTRIALIZATION IN LIFE IN THE IRON MILLS
}

by

ADAM STONE VERNON

\author{
A THESIS \\ Presented to the Department of English \\ and the Graduate School of the University of Oregon \\ in partial fulfillment of the requirements \\ for the degree of \\ Master of Arts
}

June 2020 


\section{THESIS APPROVAL PAGE}

Student: Adam Stone Vernon

Title: Troubling Ideals: Rebecca Harding Davis and the Consequences of Industrialization in Life in the Iron Mills

This thesis has been accepted and approved in partial fulfillment of the requirements for the Master of Arts degree in the English by:

Dr. William Rossi Chairperson

Dr. Mary Wood Member

Dr. Gordon Sayre Member

and

Kate Mondloch Interim Vice Provost and Dean of the Graduate School

Original approval signatures are on file with the University of Oregon Graduate School.

Degree awarded June 2020 
(C) 2020 Adam Stone Vernon 


\section{THESIS ABSTRACT}

Adam Stone Vernon

Master of Arts

Department of English

June 2020

Title: Troubling Ideals: Rebecca Harding Davis and the Consequences of Industrialization in Life in the Iron Mills

Rebecca Harding Davis's Life in the Iron Mills stands as a critique of the national ideology of progress, exposing the moral and environmental pollution it furthers and the idealist aesthetics that sustain it. While engaging in a recognizably realist exposé, targeting the despoiled industrial landscape, labor and class exploitation, and elitist spectatorship, she also employs a more symbolic aesthetic, one that furthers her critique while also pointing to the possibility of transcendence or redemption. Whether Davis intentionally innovated this hybrid aesthetic or not, it reflects a close observation of industrial reality and a strong desire to reveal to her reader the corrosive moral consequences concealed by the popular national ideology of progress. 
CURRICULUM VITAE

NAME OF AUTHOR: ADAM STONE VERNON

GRADUATE AND UNDERGRADUATE SCHOOLS ATTENDED:

University of Oregon, Eugene

University of Wyoming, Laramie

\section{DEGREES AWARDED:}

Master of Arts, English, 2020, University of Oregon

Bachelor of Arts, English, 2020, University of Wyoming

Bachelor of Arts, Spanish, 2020, University of Wyoming

\section{AREAS OF SPECIAL INTEREST:}

$19^{\text {th }}$ Century American Literature

Politics, Culture, and Identity 


\section{ACKNOWLEDGMENTS}

I wish to express sincere appreciation to Professors Rossi, Wood, and Sayre for their assistance in the preparation of this manuscript. I also thank the members of my community for their valuable input and encouragement, especially my parents Ken and Natalie, and partner, Taylor for putting up with my writing processes. 


\section{TABLE OF CONTENTS}

Chapter

Page

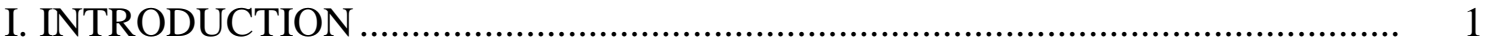

II. VISUALIZING LANDSCAPE, NATION, AND PROGRESS............................ 4

III. DAVIS'S INDUSTRIAL REALITY ........................................................ 11

IV. CLASSED CRITIQUES OF THE POLLUTED BODY ................................. 16

V. DEBORAH AS THE EMBODIMENT OF THE HYBRID AESTHETIC ........... 24

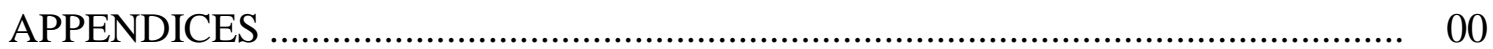

A. APPENDIX TITLE IN ALL CAPS ................................................... 00

B. APPENDIX TITLE IN ALL CAPS ................................................... 00

C. APPENDIX TITLE IN ALL CAPS …................................................. 00

[for a single appendix use this form:]

APPENDIX: TITLE OF THE APPENDIX …................................................. 00

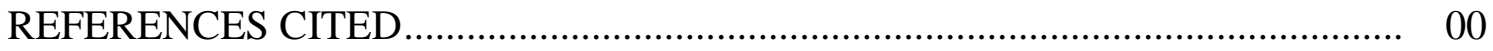




\section{LIST OF FIGURES}




\section{I: INTRODUCTION}

When Rebecca Harding Davis's novella, Life in the Iron Mills first appeared in Atlantic Monthly in 1861, manufacturing cities had already cultivated an industrial appearance through smoky skies, soot-covered landscapes, and waste from over population. This appearance was common across the eastern United States, including Wheeling, West Virginia, the town in which Davis grew up in and on which she based her story. As concepts of pollution and environmental hazard were just emerging, "citizens, business owners, legislators, courts, physicians, and sanitarians debated the consequences of coal smoke and other forms of waste for municipal economies, urban aesthetics, human health, and morality" (Gatlin 202). Anxiety from the debate was heightened by the fact that many viewed soot and smoke as a sign of industrial and national progress.

In blanketing her landscape and characters with soot and smoke, Davis's Life in the Iron Mills stands as an obvious critique of the national ideology of progress, exposing the moral and environmental pollution it furthers and the idealist aesthetics that sustain it. At the same time, she is reluctant to throw Howells" "ideal grasshopper" out with the bath water. While engaging in a recognizably realist exposé, targeting the despoiled industrial landscape, labor and class exploitation, and elitist spectatorship, she also employs a more symbolic aesthetic, one that furthers her critique while also pointing to the possibility of transcendence or redemption. Whether Davis intentionally innovated this hybrid aesthetic or not, it reflects a close observation of industrial reality and a strong desire to reveal to her reader the corrosive moral consequences concealed by the popular national ideology of progress. 
In structure, Life in the Iron Mills is bookended by images of pastoral idealizations of nature, between which are set scenes of industrial pollution and tragedy. The narrator is later revealed to be one of the characters, Deborah, a cotton-mill worker and cousin of Hugh Wolfe, an iron "puddler." As the story opens, Deborah leads the reader through the soot that covers the city into the iron mill, where we meet a group of men, representing various segments of the social elite, who, in touring the facility, encounter Hugh and his artistic creation: The Korl Woman, a statue he has chipped out of pig iron, a byproduct of milling iron. While they critique the statue, one or two suggest that Hugh could have artistic potential. But while some of them recognize this, they all deny him any help of achieving this potential and leave. As they depart, Deborah steals money from their pockets, for which Hugh is later blamed and both are arrested. This part of the story ends with Hugh's suicide in a jail cell, Deborah in the next cell mourning him, and the promise of a Quaker woman to bury Hugh among the hills. Three years later, her sentence apparently served, the woman returns for Deborah, who, having found refuge in pastoral nature and Quakerism, reveals her identity as one who has all along kept Hugh's statue, now tucked away in a corner of her library.

In criticism, this story has largely been viewed as representing "unquestionably better than any other nineteenth-century short story ... both a clean break with romanticism and the birth of realism" (Stoner 28). But reading Davis's novella under this apprehension risks missing many popular non-realist traits that permeate the text.

Leveling the generic barriers of realism or constructing them too rigidly in literary analyses tends to ignore aspects of a text which might not support one's claims. As Michael West argues in responding to Stoner, "romanticism, sentimentalism, 
regionalism, realism, and naturalism are all justifiably invoked to explain aspects of [Davis's] oeuvre, with the palm probably going to realism" (235). Whether Davis foresaw the end of Romanticism and the dawn of Realism is beyond the interest of this paper. What is clear is that Davis entertained the popular idealist imagery found in the American Romantic literary canon, while inundating it in pollution to create a hybrid aesthetic of the real and ideal. I will begin by looking into the framework of cultural ideology that Davis invokes, briefly examining how these national discourses of progress were popularly presented, before turning to Davis's critical treatment in Life in the Iron Mills. 


\section{II: VISUALIZING LANDSCAPE, NATION, AND PROGRESS}

Because of their immense popularity, landscape paintings and images can make for instructive analogues to literary descriptions of nature in the nineteenth century. Like advertising today, such images often encode or appeal to dominant ideologies regarding landscape and nation, not to mention race and identity. As Leo Marx argues, such popular portrayals of the landscape were repositories of national values, locating the landscape at the forefront of developing a national identity (228). As compelling reflections of the national unconscious, three well-known works by Frederic Church, Albert Bierstadt, and John Gast provide insight into both the national resonance and the complex refiguring of pastoral imagery in Davis's Life in the Iron Mills.

The most pronounced depictions of natural purity as it is tied to industrial progress are paintings of the Hudson River School. There some of the most recognizable allegorical depictions in the American Western aesthetic tradition combine the motifs of industrial development with sentiments of national progress, even in images where the presence of industry or the notion of "progress" seems far away.

Among the Hudson River School of landscape painters, Frederic Church's popular mid-century work stands out for its depictions of the American landscape as an ideal refuge. Painted one year before Life in the Iron Mills was published, Twilight in the Wilderness (1860) (Figure 1) depicts the woodlands of the northeastern United States against a backdrop of the mountains 


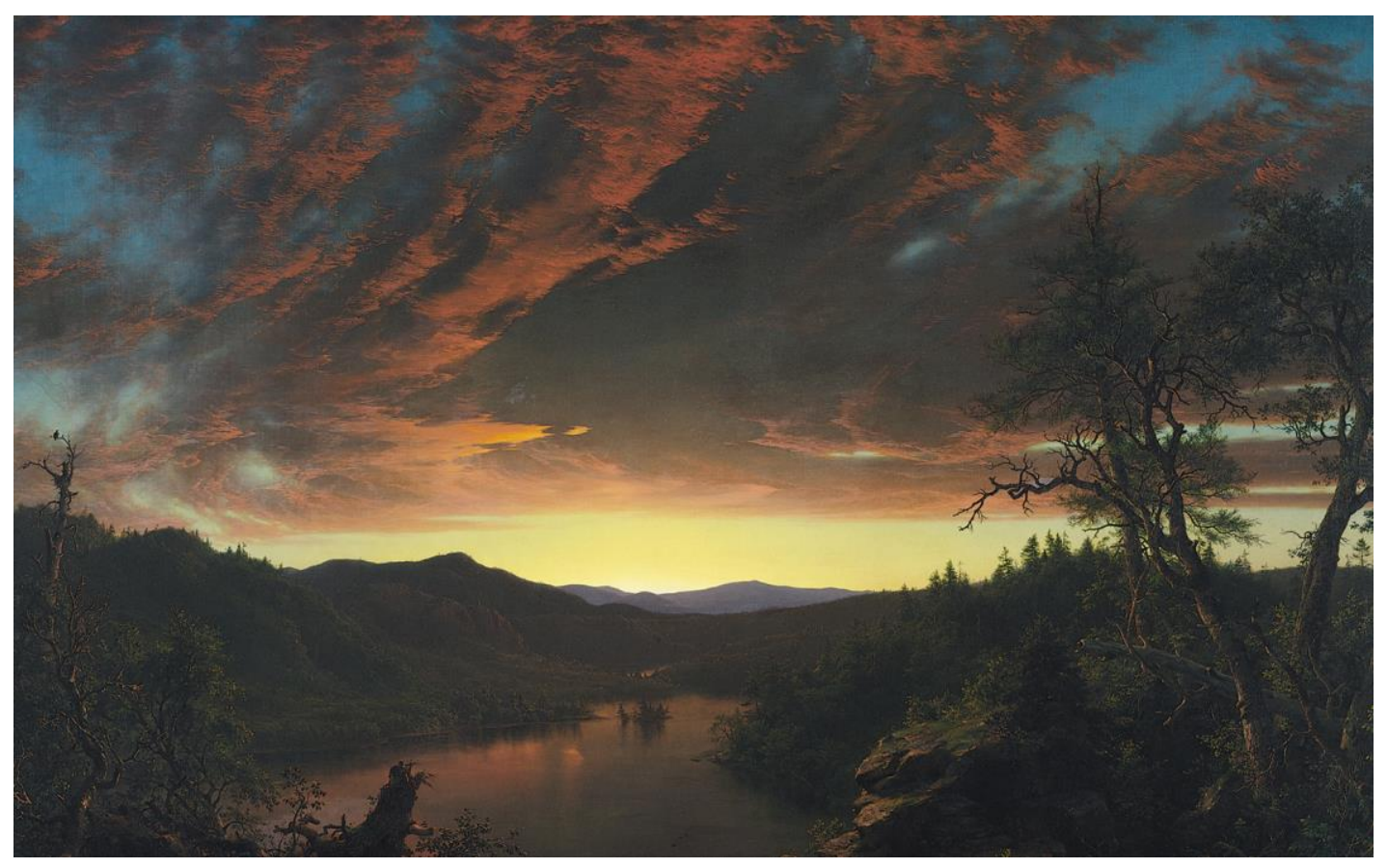

Figure 1.

based on Maine's Mount Katahdin, as a setting sun colors the altocumulus clouds. Art historian John K. Howat describes the painting as "one of [Church's] finest ever" and as "the single most impressive example of Church's depictions of unsullied North American woodlands and their most famous representation in nineteenth-century painting" (Howat, Church 90; "Twilight" 251-52). "Unsullied" by what, however, has been the subject of some speculation. In Catrin Gersdorf's study of the cultural function of the American landscape, she suggests that the idealized imagery of Twilight presents an aesthetic refuge from the pervasiveness of industrial production and pollution. She writes, "in an age when the control and disciplining of wild nature was more and more perceived as implicit in, even mandatory for the nation's progress... [Church's] landscapes suggested the presence of a sublime refuge from the perils of increasing industrialization and urbanization" (40). Church's work, here, is not taken as the sole representative of 
American Romantic landscape aesthetics, but it is clear that the public enchantment with Church's work and with the notion of expanding west were both popular escapes at the time. Thus, the idealized landscape imagery in Church's Twilight imaginatively relocates and reconciles representations of unpolluted landscapes with the development of cities, suggesting also that a pastoral national landscape can coexist with settling the west.

The refuge that Gersdorf finds inherent in Twilight thus becomes a transportable sentiment for urban spectators. The momentary escape visible in this and similar landscape paintings functions as a recognition of the presence of industrialization even though that presence is not specifically represented. In this way, the idealization of the landscape serves to erase the industrial anxieties that lie beyond the painting's frame and that threaten the real landscape this painting portrays. At the same time, the effect of the idealized landscape is that ideologies of pastoralism and refuge from industry are represented without the visible consequences of industrial pollution or the anxieties it generates. If, therefore, these spaces exist not only outside of the city, but within the expanding nation, their very presence helps to fuel ideologies of unfettered national progress, while they energize expansionists aiming to travel west.

Accompanying the work of Frederic Church, Albert Bierstadt held an aesthetic vision of idealization in nature that also maintained the American national ideology of industrial progress. Within the national rhetoric of Manifest Destiny, Bierstadt's depictions of western natural purity are meant to invoke nationalism through geographical and symbolic expansion. These representations of the territory house ethereal and ideal qualities meant to endorse the national ideology of opening the frontier for civilization and economic development. In this context 


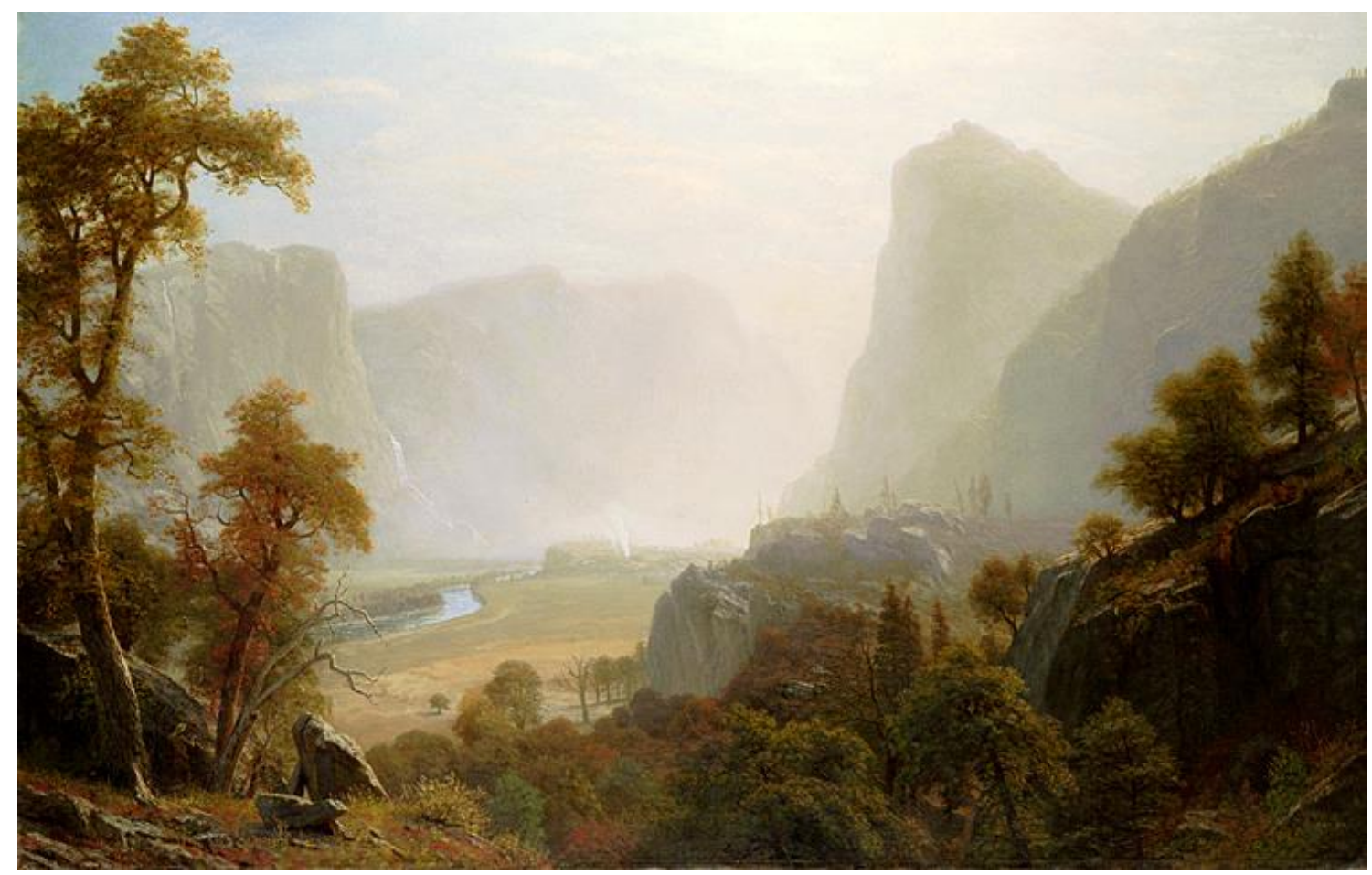

Figure 2.

Bierstadt ties the pastoral features of the landscape to industrial development and expansion by "taming wilderness through the aesthetic" (Imbert n.p.).

The idealized nature in his 1874-1880 painting, Hetch Hetchy Valley, California (Figure 2) unquestionably portrays this. The painting is backgrounded with the famous granite slabs of the Yosemite Valley as they recede into a luminous and infinite mist, while the foreground depicts leaves, trees, moss, and a Euroamerican figure, halfconcealed behind a boulder in the left foreground, surveying and sketching Hetch Hetchy Valley. His outward gaze into the seemingly endless mountain range mimics how the nation gazed westward after the Civil War. The puffs of smoke in the middle ground could be encampments of Miwok and Paiute peoples (Jones 74). But due to the settlement of this valley in the 1870 s, it is far more likely that these indigenous 
populations would already have been displaced by western expansion. Bierstadt may therefore have included theses encampments to evoke a white-settler discovery of them, even though they would not have existed when the image was actually made.

Bierstadt thus gives us the sense that the west was Edenic for settlers looking towards the frontier. Representing the Yosemite Valley as an ideal landscape from the perspective of the surveyor in the frame exercises the possibility of settlement, but it also suggests an element of discovery together with subsequent development as the surveyor sketches the land, literally drawing and quartering it for development. In this way, his gaze, too, is linked to industrialization and thereby to an idealization that erases the actual history of displacement. ${ }^{1}$ While quietly acknowledging the erasures of race and tribal identity that are consequent of the expansion, this painting presents an appeal to dominant ideologies regarding landscape and nation. In this way Bierstadt creates a compelling reflection of the national unconscious, and in doing so, simultaneously leaves traces of displacement and genocide tied to the pastoral imagery. As detailed depictions of the ideal, Church's and Bierstadt's works reframe even the traces of Indigenous destruction as progressive national ideology.

Some depictions of "progress" were not painted as delicately as Church and Bierstadt did. Little ambiguity is present in John Gast's 1872 chromolithographic print, American Progress, which unequivocally weds the territorializing of the western landscape to industry. The Library of Congress online catalogue describes American Progress (Figure 3) as "an allegorical female figure of America leading pioneers westward, as they travel on foot, in a stagecoach, conestoga wagon, and by railroads, where they encounter Native Americans and herds of bison" (n.p). This caption is an 


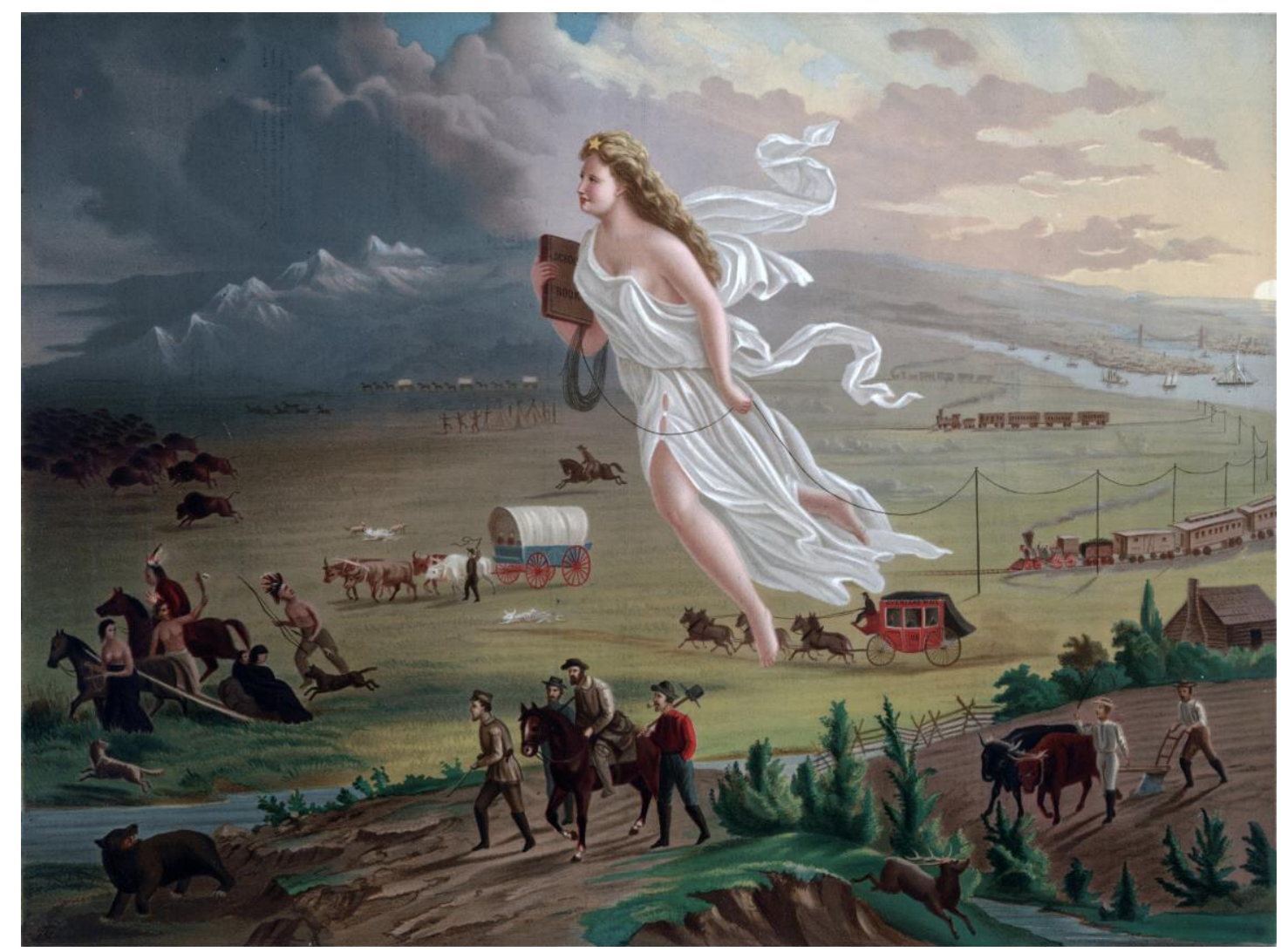

Figure 3

example of rhetoric still in use today to produce the national ideologies of progress and Manifest Destiny as it whitewashes the dislocation of native peoples as an "encounter," while maintaining its sentiment of western expansion and the progression of industry. As in Bierstadt's landscape, the idealist aesthetic in this painting serves to erase the realities of genocide and indigenous displacement that inherently underpin the tableau scene. But here the national ideology, including its brutality are rendered explicitly.

In this print the angelic figure named "Progress" strings telegraph wire with one hand and holds a school book with the other, heading westward from the industrially developed east towards the pristine, cloudy Rocky Mountain range. Native peoples, including bare-breasted women, as well as wild animals are all depicted are fleeing before their clothed, advancing white counterparts. Similarly, white technologies - trains 
and wagons - appear superior to Native transports, while white agricultural practices displace Native lifeway practices. The mountains here are only scenic elements, much less imposing than in Bierstadt's Hetch Hetchy. With its undulating lines and absence of obstacles, nature is clearly and ultimately pastoralized in this print. It is understood that the transcendent figure of the angel represents progress, bringing industrialization and white settler cultural customs to the undeveloped West. The ideology produced by Gast in this print carries the rhetoric of technological production as it is tied to western expansion and national progress; the consequences are erased by these idealized depictions of progress. As the angel stakes the land with telegraph wire, the impression given to the viewer is that this land is staked for American industrial development.

Images like Gast's produce national ideologies over and over until these ideologies become expectations fused into the popular discourse. These expectations are the formulation of the ideal. When expectations of progress do not align with reality, the popular sentiment would be that progress is not occurring. By leaving the negative consequences of progress unacknowledged, idealist authors and artists produce an aesthetic that serves to reaffirm to the viewer the progressive, exceptional, and popular character of these ideals. This is especially clear when the pastoral and the industrial are positioned next to each other, revealing the contradiction inherent to the national ideology of progress; the more this land is settled and industrialized, the less it will exist in its ideal form. Although this contradiction was less visible in popular landscape painting at the time, it was certainly present. Thus, the images of Gast, Bierstadt, and Church all sanitize the real effects of western expansion and industrialization, glossing over the apparent contradictions within their work. 


\section{III: DAVIS'S INDUSTRIAL REALITY}

By exposing industrial realities throughout Life in the Iron Mills, Rebecca Harding Davis challenges the reader to disrupt these idealized sentiments. The contradiction between industrial pollution and pastoral idylls is much more visible to Davis's late-twentieth and twenty-first-century readers than it would probably have been to her nineteenth century readers. If combined today, natural and industrial rhetoric would likely have direct political underpinnings, commenting on the corrosive relationship between industrial and technological pollution and a rapidly changing climate. In the nineteenth century, these anxieties were nascent but not generally realized as contradictory.

As her opening scenes vividly demonstrate, the consequences of industrialization are inseparable from nature in Davis's novella. Juxtaposing an ideal, pastoral vision of nature found outside the town with its soot-buried main setting, Life in the Iron Mills represents an indictment of national progress and industrialization rather than a glorification of it. Unlike Church, Bierstadt, and Gast, Davis does not erase what ideal depictions of landscape elide. The consequences of industrialization are made clear through the pollution of nearly all the natural imagery described in her story.

The narration of the story begins with the description of a squalid mill town whose natural purity is defiled by bituminous grime. Immediately in Life in the Iron Mills, the narrator, Deborah, emphasizes how the town's general populace is nearly suffocated with polluted air: "The sky sank down before the dawn, muddy, flat, immovable. The air is thick, clammy with the breath of crowded human beings. It stifles me" (1706). Here, the cropped sentences and the thickness of the atmosphere stifle the 
reader, too. In these first sentences of the story, the narrator thus immerses her readers in the un-breathability that the laboring characters - whom they will soon meet — and the city inhabitants experience, forcing the reader to confront an unavoidable industrial reality. So pervasive is this reality to Davis's characters that it is literally the air they breathe.

As noted earlier, Davis's description of the air is a response to a popular sentiment that soot-filled air was a metric of success in the early industrial era. Jill Gatlin details the point that in nineteenth-century ideologies of national progress, such conditions were not seen as an impediment to natural purity. "In 1857," she writes, "the historian, businessman, and Board of Trade President George Henry Thurston-a prominent representative of Wheeling's infamously smoky rival, Pittsburgh—declared 'the shadow of [Pittsburgh's] smoke' to be one of the few recognized 'report[s] of her progress"” (Thurston qtd. in Gatlin 202-203). Thurston would continue to describe Pittsburgh as it peered through dense smoke and soot as "attractive" and lovely" (Thurston, 11). Thurston's rhetoric attempts to locate the industrial pollution as a marker of progress, though, not just limited to Pittsburgh. That towers of soot represent signs of progress for Thurston and others of the time suggests that progress in the United States necessitates industrial development that will include the as-yet pastoral or bucolic landscape.

As Davis details the state of the town in which Life in the Iron Mills takes place, her position becomes quite contrary to Thurston's, Church's, and Bierstadt's imaginings of industrialization as a marker of national progress. Instead, she uses the production of soot as a symbol for the degradation of the surrounding nature and laboring bodies, as it 
layers the landscape, cityscape, people, animals, and religious figurines. Although scholarship by Gatlin and others has focused on air pollution as an early environmental hazard, there has not been much to say about contemporary efforts to understand the meaning of what the soot actually covers. In the story, soot and smoke inflict damage on seemingly every object. Emitting from the great chimneys of the iron foundries, the smoke settles on the "wharves," "the dingy boats," "the house-front[s]," "the yellow river," "the two faded poplars," and "the faces of the passers-by." (1706). To further emphasize the damage, Davis juxtaposes these images with those of ideal pastoral beauty available just outside of town: "odorous sunlight, quaint old gardens, dusky with soft, green foliage of apple-trees, and flushing crimson with roses, - air, and fields, and mountains" (1707). This juxtaposition serves not only to underscore the despoliation of the town and everything in it, thanks to the iron mill operation. It also activates the same transcendent ideal we have seen associated with the pastoral promise of national landscape in Church's Twilight, Bierstadt's Hetch Hetchy, and Gast's Progress; all these images are illustrated as being just up the river. The refuge the narrative voice creates for the reader here is ideal natural imagery in the mountains, up the river, and away from the industrial runoff. Notably, it is not distinct from the refuge found in Church's Twilight or the landscape the surveyor gazes upon in Bierstadt's Hetch Hetchy Valley. Author and artists all use imagery of nature in this instance to transcend the imminent anxieties of industrialization. Though, finding resolution is a different process for an aesthete looking at a landscape painting and the industrial laborer in a mill. The rising action of Life in the Iron Mills shows that reveling in pastoral idylls was a refuge for those entrenched in industrial realities, but not a solution. As Deborah's narrative voice draws her reader's 
attention back downstream to the city covered in soot, it becomes visible to the reader that natural refuge is inaccessible to most of the "crowded human beings" in the town (1706).

Davis's critical idealism is not limited to the landscape. As the narrator follows the soot as it travels inside the house, she describes how it drapes the figure of an angel and a canary in the grime: "Here, inside, is a little broken figure of an angel pointing upward from the mantel-shelf; but even its wings are covered with smoke, clotted and black. Smoke everywhere! A dirty canary chirps desolately in a cage beside me. Its dream of green fields and sunshine is a very old dream,- - almost worn out, I think." (1706-7).

In her foundational work on Davis bridging the gap between Romanticism and Realism, Sharon Harris suggests that Davis uses the angel here as a form of repudiation towards indifferent Christian values, denying traditional Christianity as a means to alleviate the nation's social ills. Harris writes, "Its wings are broken and smoke-covered, making flight (transcendence) impossible. Befouled, it is now earth-bound" (15). In describing Davis's impatience with Christianity, Harris makes an important case for the immobility of the angel. Because the angel is broken and grimy, it cannot transcend to Heaven, indicated by its pointing upward. But the labor-centered, industrial-capital context of the symbolic angel, the fact that it is covered with industrial waste, is not taken up in Harris's work. Yet it is the soot, coloring the figure of the angel black, that conveys a feeling of inescapability from the iron mill, leading the narrator to wonder if social remediation and transcendent hope may indeed be gone forever. In this way Davis uses the grime-covered angel to address both the real and the ideal within the national 
ideology of progress, finding that industrialization produces not only physical waste but also despair.

As seen with Gast's angel, transcendence is linked in popular imagery with a promised future for America — though for Davis neither "progress" nor the future is defined in terms of westward expansion. Unlike in Gast's print and the futurity promised by the progress of the angel, Davis's angel is immobilized by the pollution while the past visions on the landscape are remembered. Whereas the doctrine of Manifest Destiny carried connotations of divine providence, in which America was destined by God to expand westward, Davis's polluted angel emphasizes the contradiction that if this land is ordained as an American right to settle and industrialize, that land will also be polluted by that settlement and industrialization. Thus, although she does not directly address western expansion, she uses critical idealism with the figure of the angel to point to the consequences of industrialization.

Significantly, though, transcendence for the angel and hope for the industrialized landscape is not entirely lost in this scene. While the angel and the "very old dream" remain inside the reaches of industry, the pastoral images of green fields and sunshine and the possibility of the transcendence are also tied together through the image of the angel. That the dream is "almost" worn out suggests that the narrator (and the author) have not quite given up on the possibility of transcendence. 


\section{IV: CLASSED CRITIQUES OF THE POLLUTED BODY}

The central tragic drama of Life in the Iron Mills concerns an encounter between the iron worker, Hugh Wolfe, and representatives of the social elite, who are touring the mill. These include: the son of the owner of "Kirby \& John's Mill," Kirby; Clarke - the son of Kirby and an overseer; Doctor May, the town physician; a reporter for one of the city’s papers; and Mitchell, brother-in-law to Kirby.

In her critique of class and labor exploitation at this juncture, Davis furthers two aesthetic aspirations of nineteenth-century literary realism: a sensitivity to class experience and a focus on a contemporary quotidian reality previously considered too banal for literary representation. Amy Kaplan, Rachel Bowlby, and others have argued that the practice of presenting such reality as a spectacle to an upper- and middle-class readership that is "just looking" implicates realist authors in the formation of consumer

culture. ${ }^{2}$ By contrast, Davis's narrator treats her readers more like the social activist she is, inviting them "down" to witness the life ordinarily beneath them: "I want you to hide your disgust, take no heed to your clean clothes, and come right down with me,- - here, into the thickest of the fog and mud and foul effluvia. I want you to hear this story...I want to make it a real thing to you." (1707).

Not only is the audience imagined as well-dressed here, while hinting at their consumerism, they are invited to join the narrative voice in the grime of this "real thing." The purpose of the leisure-class audience presence is immediately clear: they are there to hear a story and witness the realness of something. The foulness in which the audience becomes entrenched is in fact the same foulness that Davis's laboring characters reside in as they work in a mill that sustains the industrial development of the United States in the 
nineteenth century. By inviting her readers down, the narrator thus gives them a look at the people who produce the wealth of the steel industry. But she does not let her audience leave without themselves being stained by the reality of hopelessness and human suffering in the mill. In this way, the reader must acknowledge the realities tied to national industrial progress while Davis thus layers tropes of the ideal national landscape with images of industrial waste to make Life in the Iron Mills versitic ${ }^{3}$.

At the same time, Davis encourages the notion that, in contrast to the disabused reader, for the group of elite men, life in the iron mills indeed is a spectacle as they tour "just looking" more or less passively. In fact, Deborah tells the reader that most of the men are here "merely for amusement" (1714). Ironically, moreover, the tragedy of the story turns on the effect of their presence on Hugh, the iron worker.

The touring elite's descent down into the pollution of the mill is announced through a growing silence, with the usual din diminishing as the men pass the furnaces. The presence of the party is portrayed as inspiring a mixture of reverence and intimidation among the workers. Hugh, who had acquired the habit of "seiz[ing] eagerly every chance that brought him into contact with this mysterious class that shone down on him perpetually with the glamour of another order of being," recognizes the softening atmosphere by an omnipotence that they seem to emit (Davis 1714). Here the mysteriousness of their presence, regarded as a light that shines down and illuminates Hugh, is formalized in messianic language. To Hugh, these men are of another order of being. They exist outside his industrial reality, beyond the grip of the mill and the grime. Yet the presence of these men is not only foreign and seemingly superior to Hugh. His veneration suggests that to him they have succeeded in doing what he desires: they have 
transcended to an existence beyond industrial labor and the suffocating layers of pollution. To Hugh, Mitchell's idealized intellect and aesthetic eye are signs of this order, distinguishing him further. In detailing Mitchell's intellectual idealism, the narrator describes him as

a man who sucked the essence out of a science or philosophy in an indifferent, gentlemanly way; who took Kant, Novalis, Humboldt, for what they were worth in his own scales; accepting all, despising nothing, in heaven, earth, or hell, but one-idead men; with a temper yielding and brilliant as summer water, until his Self was touched, when it was ice, though brilliant still. (1715).

What might normally be read as a compliment to a nineteenth-century American intellectual does not have the same effect here. In locating Mitchell in a German intellectual tradition popular with Emerson and others in the United States at the time, Davis presents the idealist American intellectual as one whose ideologies are theoretical and philosophical, considerably inapposite within an industrial landscape. "Such men," she adds, "are not rare in the States" (1715). Needless to say, the brilliance of the "summer water" that characterizes Mitchell's temperament contrasts sharply with the ash-producing furnaces that surround him. This imagery also recalls the idyllic landscape described by the narrator at the beginning of the text. But while this warm, summery imagery may be a testament to Mitchell's brilliance and temperament, once his deeper Self is touched, that warmth turns to ice. Thus, when Mitchell encounters something appreciably aesthetic, as he does Hugh's statue of the Korl Woman, he exhibits the keen ability as an aesthete to understand artistic intentions; but when this happens and he is moved, his humanity freezes over. 
The scene of the group's encounter with Hugh's statue, in the depths of the mill's Dantesque inferno, is perhaps the most powerful and complex of the story. The artistic valuation of the industrially-sourced korl woman - a statue whittled out of scraps of smelted pig iron—arises from a discussion among the men touring the mill. As they stumble upon the statue, frightened at first, they begin to inspect it further. Kirby makes jokes about the statue not being emaciated, so it must not be hungry. Dr. May looks at it with a physician's eye, admiring the impression sculpted in the statue; it must have labored, as it's body shows the same stained muscles as mill's laborers. Mitchell, initially, is "strangely touched" by the work.

Although Mitchell's opinions are ambiguous, it is clear is that he reads the statue as Hugh intended it to be read, acknowledging "the soul of the thing" (Davis 1717). As the narrator describes it, the statue powerfully suggests "one idea: there it was in the tense, rigid muscles, the clutching hands, the wild, eager face, like that of a starving wolf's. The similarity between "wolf" and "Wolfe"—Hugh's last name—should be acknowledged. As Hugh remarks, "she be hungry" (1716), as Mitchell realizes, too. Significantly, the statue does not conform to any ideal Western model of beauty; yet it also embodies "one idea." In this way, it makes vivid to Mitchell, who is touched "strangely" by it, what the narrator describes as a "reality of soul starvation." As a representation of the realities that industrial laborers confront within the soul-destroying institution of industrialization, the statue of the Korl woman manifests through a medium Mitchell can appreciate, the penurious economic conditions, bodily degradation, and deeper suffering of the workers. 
Mitchell's icy self-interest becomes especially visible when he turns on Hugh as the object of his mockery, distancing himself from the art and artist that touched his "Self." "Wolfe stammered, glanced appealingly at Mitchell, who saw the soul of the thing, he knew. But the cool, probing eyes were turned on himself now,- -mocking, cruel, relentless." Having been (in Rachel Bowlby's phrase) "just looking” as he passively toured the mill, Mitchell has found himself unexpectedly confronted by a work of art, causing him to formulate a different conception of his own identity. This conception presumably includes the recognition that his own intellectual and moral ideals are implicated in the reality of industrial suffering evident in Hugh's art, a testament to his latent genius. In mocking Hugh, he thus distances himself from his own negative selfimage.

This outward projection leads Mitchell to abjure himself of any social obligation towards the laborers, a response made all the more blatant through his messianic language. He does not help Wolfe by becoming his benefactor because "it would be of no use," Mitchell claims, as he "is not one of them" (1719). The distance Mitchell puts between himself and the laborers is plentifully evident as he continues this dialogue:

"Think back through history, and you will know it. What will this lowest deepthieves, Magdalens, negroes—do with the light filtered through ponderous Church creeds, Baconian theories, Goethe schemes? Some day, out of their bitter need will be thrown up their own light-bringer,--their Jean Paul, their Cromwell, their Messiah.” (1720)

This line implicates Mitchell as a possible — though unwilling — messiah figure, seeming to suggest that his renunciation of this role also carries the recognition that he could 
potentially play this part for Hugh. But finally, there is no positive resolution or hope that Hugh's statue has imbued in Mitchell anything that will cause him to confront the industrial realities of exploitative labor practices or soul-starvation that he witnessed, solely because they muddy his idealist conceptions of Self.

While the narrator describes Mitchell's response to the statue, Davis also makes clear Hugh's simultaneous self-recognition, in the same conversation, of his own potential as an artist, the possibility that he might have a life outside the mill through his sculpting. ${ }^{4}$ She writes: "[t]hink that God put into this man's soul a fierce thirst for beauty, - to know it, to create it; to be- - something, he knows not what, —other than he is." (1713). Not only is this thirst for beauty never quenched, Davis seems to suggest that God had artistic intentions for Hugh, but due to his status as a laborer and the pollution of industry, this beauty would never be actualized. The possibility of transcendence is thus corrupted throughout the novella as both the reader and Hugh learn that he cannot overcome his social caste nor the pollution that layers him and his landscape. In disrupting the possibility of Hugh's actualizing his artistic potential, Davis displays the consequences of industrial capitalism for both the body and soul of the laborer.

The oppression of the laboring body, however, is portrayed not only through excessive physical demands and polluted working conditions. The story also documents a kind of ideological pollution or internalization of industrial waste. After his encounter with the elite men, Hugh compares his own body to that of Mitchell:

His squalid daily life, the brutal coarseness eating into his brain, as the ashes into his skin: before, these things had been a dull aching into his consciousness; tonight, they were reality. He griped the filthy red shirt that clung, stiff with soot, 
about him, and tore it savagely from his arm. The flesh beneath was muddy with grease and ashes, - and the heart beneath that! And the soul? God knows.

Here, Davis uses a simile to demonstrate how the soul-destroying industry erodes Hugh mentally and physically, describing the ash as a part of his body. The "dull aching into his consciousness" suggests that this erosion is chronic, finding that the pollution and his consciousness are becoming indistinct. Significantly, Hugh realizes that the pollution is not just on the surface of his skin: it is a part of his body and it becomes him. Blackened with industrial waste, his skin is not clean like the white hand of Mitchell (1715). And whereas Hugh's besotted face is bent to the ground by exploitative labor practices, Mitchell "was an amateur gymnast,_- -hence his anatomical eye; a patron, in a blasé way, of the prize-ring," and thus further masculinized by his interests in boxing and physicality (1707).

The description of ash in the passage above thus mirrors the pollution as it eats its way into Hugh's skin, heart, and soul. The tearing of his shirt marks Hugh's realization that it is not just his shirt that is stained and that the pollution is not just external to his body. He cannot tear it away because, throughout his "squalid daily life," the industrial waste has become internalized in his body and —as the narrator asks the reader—his soul.

At the same time the tearing of his shirt also marks a moment of self-realization and reflection for Hugh. The pollution of his body is described this way to demonstrate how the art that Hugh produces is a product of his reality. Hugh models the statue after his reality because that is what he is familiar with; it is not ideal like Mitchell's aesthetic but rather conveys the straining, suffering, and pollution that are all found within an industrial reality. When compared to the ideal national ideologies, laborers like Hugh fall 
short as they must confront the realities of industry that idealism erases. As he looks at himself after his confrontation with Mitchell, he realizes the magnitude of the "higher order" that Mitchell belongs to and that his own polluted body falls short in comparison to Mitchell's ideal masculine body. In this respect, Davis contrasts the idealist and realist body here not so much to critique the ideal. Rather, through the illustration of the polluted body, she sheds light on the degradation of the natural form by industry, illuminating how the site of the body cannot be ideally formed or conceptualized when confronted with industrialization.

Here it is important to remember that the medium of pig iron is not just what is available for Hugh's art; it also represents both a resource of the industrial landscape and an excess by product of the iron industry, not unlike smoke and soot. Like Hugh, the statue's body is a product of its landscape. The excess material is sculpted and only ideally aestheticized when the gentlemen discern its (and Hugh's) aesthetic valuation. Like the vision of the industrial landscape the narrator presents, viewing the excesses of industry dramatically reconfigures the way both the landscape and the sculpture are seen. Thus, Davis invites the reader to look at imagery that does not attempt to elide the consequences that industrialization and the ideology of national progress attempt to erase. That this imagery has been polluted through its industrialization, suggests how the realist and ideal aesthetic formulations in the story both serve to critique effects of industrial production, including its effects on the industrial laborer. As the landscape is carbonized with bitumen, the sculpture becomes a referent point from which to view the idealism and idealist aesthetics of industrial capitalism. 


\section{V: DEBORAH AS THE EMBODIMENT OF THE HYBRID AESTHETIC}

As we have seen, Rebecca Harding Davis's hybrid aesthetic in Life in the Iron Mills uses co-existing ideal and realist elements to present a critique of the national ideology of industrial "progress" and the urgent need for broad, humanist labor reform. In many ways, the figure of the Korl woman, its creation and complex reception, epitomizes this aesthetic. But a similar hybridization is perhaps best exhibited in Deborah herself. As both character and narrator, Deborah functions on two different levels of the story, but is implicated as both a realist figure and an idealist figure. Davis's achievement is evident in the way Deborah weds these two critiques, enabling their co-existence, both carried out in the service of social reform.

Retrospectively, Deborah is quietly a part of each of the key scenes that this analysis has addressed. Her presence in the story is all the more interesting because the reader often forgets that she is either present or narrating. When the reader is invited down to the filth and effluvia by the narrator to witness the suffering and pollution that occurs within the mill—bodily or otherwise — it is Deborah speaking. When the landscapes within (and beyond) the reaches of industry are described, it is Deborah doing so from the window of her old home in the city, or from her new home with the Quakers (1731). Lastly, when Mitchell evaluates the statue and Hugh, washing himself of both, Deborah hides in a pile of ash, only entering the scene when noticed by Kirby or while stealing Mitchell's pocketbook (1722). What is significant about Deborah's characterization and narration is how they both embody realist and idealist aesthetics, while simultaneously critiquing what those aesthetics portray ideologically. 
As a character, Deborah performs a realist role as thief, unreciprocated lover, and disabled woman. Self-described as having a "hunchback" early in the story, the reader realizes the extent to which her disability amplifies her compassion of bringing Hugh his meal in the mill across town: "It was far, and she was weak, aching from standing twelve hours at the spools. Yet it was her almost nightly walk to take this man his supper, though at every square she sat down to rest, and she knew she should receive small word of thanks" (1710). Later, we find out through Deborah that Hugh's "soul sickened with disgust at her deformity," though he remains kind to her (1712). Davis describes Deborah as unappreciated, belabored, and pained, because she wants to demonstrate what life is like in the iron mills; there are no ideal love stories or ideal bodies in this reality of suffering and exploitation. Instead, there is a reality that requires small compassionate endeavors in order for the characters to survive. Davis builds on this point, having Deborah ask, "[a]re pain and jealousy less savage realities down here in this place I am taking you to than in your own house or your own heart[?]" (1712). Pain and jealousy are markers of a "less savage realit[y]" because they are motivators that disrupt the "dull consciousness" attributed to both Hugh and Deborah.

These moments develop Deborah's character as a caring individual lacking mobility and immersed in an industrial system. But it also serves to contrast figurations of ideal body aesthetics. Contrasting Mitchell's characterization, Davis writes of Deborah, "There was no warmth, no brilliancy, no summer for this woman" (1712). ${ }^{5}$ This comparison uses the same language used to describe Mitchell's brilliance, but it also draws a difference between how the two characters are depicted. Positioning Deborah within a realist aesthetic is thus one way to critique the reality of the labor industry, 
giving the reader a glance at what humanity and the body both look like through class exploitation and wage labor.

At the same time, realist depiction does not prevent Deborah, especially, as narrator, from participating in a more symbolic aesthetic and, with it, maintaining the possibility of redemption and transcendence. This symbolic aesthetic can be seen through Deborah's adoption of Quakerism and with it the pastoral landscape from which she narrates part of the story: "a homely pine house, on one of these hills, whose windows overlook broad, wooded slopes and clover-crimsoned meadows, - niched into the very place where the light is warmest, the air freest" (Davis 1731). The imagery here is reminiscent not only of what is seen contemporaneously in Church or Bierstadt, but also the pastoral landscape that exists beyond the reaches of industry, up the river, at the beginning of the story.

Significantly, this land is characterized not only by virtue of its idyllic description, but_also by being markedly free from industry. The air that stifles narrator and reader early in the story thus becomes free of pollution and salubrious again in the end.

Deborah's access to and description of this land suggests that the pastoral landscapes are still accessible amidst rampant industrialization, but that the latter is detrimental to the landscape, and relationship between the land and industry is unsustainable. By both beginning and resolving the story with ideal imagery, then, Davis suggests that pastoral forms of nature are not absent in the Industrial Era, just dislocated from industrialization. If the effects of industry on the national landscape are invisible in the work of Bierstadt and Church, Life in the Iron Mills presents that same landscape as polluted and warped. 
This warping of natural form is seen in both Deborah's description of the industrial landscape and in her body; yet in the end she transcends the pollution. Interestingly, as a hybrid figure, both character and story-teller and enacting both realist and ideal aesthetics, Deborah is analogous to the polluted angel whose body points in two directions and carries out both critiques. Oppressed and possibly deformed by mill life conditions, in Quakerism at the end of the story, she finds pastoral simplicity and redemption: "There is no need to tire you with the long years of sunshine, and fresh air, and slow, patient Christ-love, needed to make healthy and hopeful this impure body and soul." (Davis 1731). If this spiritual and natural rejuvenation has made Deborah healthy and hopeful, however, it has not dulled her sense of the tragedy and suffering recounted in her story of Hugh Wolfe, the story she not only tells but still, like the angel, embodies. yet participates suffered transcending the illnesses and pollution of the industrial reality she was immersed in. Davis offers this redemption and transcendence to her readers as bookends for this story, precisely because she wants to remind them through their own dull consciousness that there is hope for the starved soul. Perhaps the recognition of these natural and spiritual survival in an industrial reality is the secret that Rebecca Harding Davis refers to in the line, "I want to make a thing real to you" (1707). Ultimately, this secret is left open to interpretation.

Life in the Iron Mills is thus a beautifully complex narration that portrays a problem rooted in the abuses of industrialization and the social obligations tied to them, leaving the reader in utter despair of hope for Hugh's transcendence as it fades across the pages. This hope is ultimately rejuvenated through Deborah's Christian cosmology, escaping the pollution and finding health and hope among Quakers. Though, the 
hopelessness that persists throughout the narrative mirrors the hopelessness that governs the lives of the laborers indefinitely. What is clear from the text is that the national ideology of progress and industrialization results in the abuse of laborers and the land. Further, the solution to this problem is not found in idealizations of figures or landscapes - in fact, idealizations seem to erase the consequences of industry entirely. As Davis makes these consequences real to us, she also implicitly asks the reader to address it. Simultaneously, this is a request for readers to adjust their understanding of ideal romantic aesthetics and orthodoxies in order to engage what, in the subtitle of her next book, Davis calls "story of to-day." By addressing the stories of the day- the stories that account for the glaring problems of industry and wage labor-Davis politicizes her writing, shedding light on figures that constrained to work in dark mills, who cannot leisurely indulge in ideal forms of art. By making this real to the reader, Davis imbues the beginning and the end of this her first story with optimism, inspiring the reader to acknowledge the consequences of the real hidden within the ideal.

\section{Endnotes}

${ }^{1}$ In fact, Hetch Hetchy Valley was completely industrialized, being inundated by the construction of the O'Shaughnessy dam in 1923, creating a reservoir that would deliver water 167 miles west to San Francisco.

${ }^{2}$ In the introduction of her foundational text, The Social Construction of American Realism, Amy Kaplan proposes that Realism is "now related primarily to the rise of consumer culture in the late nineteenth century, in which the process of commodification makes all the forms of the quotidian perform in what Guy Debord has called the 'society of the spectacle"” (7). To Kaplan, this figuration of Realism is "a means of engaging in 
one of the most common activities of modern urban life: 'just looking"' (7). Quoting the title of Rachel Bowlby's 1985 book, Just Looking: Consumer Culture in Dreiser, Gissing, and Zola, Kaplan associates literary realism with spectatorial activity: as a consumer would browse aisles, so the reader browses the pages of a text, just looking at some unexplored aspect of society which he or she can take or leave.

As this pertains to Davis's most prominent characters, Mitchell and Hugh, the quotidian spectacle is marked by their continuous, incessant participation in industrial labor rather than finding inspiration and conceptions of the Self in nature. The author thus immerses her characters together with her activist first-person narrator in this industrial reality, representing the laborers as a spectacle for the elite classes portrayed in the story.

Diana Knight focuses on the late-nineteenth-century moment of consumer identity formulation, suggesting that literary realist texts employ "the proliferation of visual images [to constitute] both society and the self in this period (shop windows, adverts, photography, cinema)," a self-fashioning is generated by passive observation (197). Thus, the reader finds meaning in the quotidian, but effectively washes themselves of any obligation of action or intervention.

${ }^{3}$ Defined: one who believes in or practices the rigid representation of the truth or reality in literature or art. "verist, n." OED Online, Oxford University Press, March 2020, www.oed.com/view/Entry/222529. Accessed 27 May 2020

${ }^{4}$ Although Davis makes it clear early in the novella that hope is not something real to these laboring characters, Hugh seems to be the exception (1707). Through his art, she suggests, he has built up a sense that he might be more as artist and as human being: "He looked at himself with sudden loathing, sick, wrung his hands with a cry, and then was 
silent. With all the phantoms of his heated, ignorant fancy, Wolfe had not been vague in his ambitions. They were practical, slowly built up before him out of his knowledge of what he could do. Through years he had day by day made this hope a real thing to himself,_ — clear, projected figure of himself, as he might become.” (1720).

${ }^{5}$ Compared to the lines describing Mitchell: "brilliant as summer water, until his Self was touched, when it was ice, though brilliant still" (1715).

${ }^{6}$ Davis's second book, Margaret Howth: A Story of To-Day, was serialized in Atlantic Monthly in 1862. 


\section{REFERENCES CITED}

“American Progress." Library of Congress Prints \& Photographs Online Catalogue, Library of Congress, 1 Jan. 1873, www.loc.gov/pictures/item/97507547/.

Bierstadt, Albert. "Hetch Hetchy Valley, California.” SmartHistory, 2018, Wadsworth Atheneum Museum of Art, smarthistory.org/bierstadt-hetch-hetchy-valley/.

Church, Frederic. Twilight in the Wilderness. 1860, Metropolitan Museum of Art, New York, en.wikipedia.org/wiki/Twilight_in_the_Wilderness\#/media/File:Twilight_in_the_ Wilderness_by_Frederic_Edwin_Church_(3).jpg.

Davis, Rebecca Harding. "Life in the Iron Mills." The Norton Anthology of American Literature, ed., Nina Baym and Robert S. Levine, B. W.W. Norton \& Co. New York, 2012, pp. 1706-1732.

-------- Margaret Howth: Literature House/Gregg Press, New Jersey, 1970.

Gast, John. “American Progress.” Library of Congress Prints \& Photographs Online Catalogue, 1873, www.loc.gov/pictures/item/97507547/.

Gatlin, Jill. "Disturbing Aesthetics: Industrial Pollution, Moral Discourse, and Narrative Form in Rebecca Harding Davis's 'Life in the Iron Mills." Nineteenth-Century Literature, 68. 2 (2013), pp. 201-233. JSTOR, www.jstor.org/stable/10.1525/ncl.2013.68.2.201.

Gersdorf, Catrin. "History, Technology, Ecology: Conceptualizing the Cultural Function of Landscape." Icon, 10 2004, pp. 34-52. JSTOR, www.jstor.org/stable/23787126. Accessed 24 Apr. 2020.

Harris, Sharon M. "Rebecca Harding Davis: From Romanticism to Realism.” American Literary Realism, 1870-1910, 21. 2 1989, pp. 4-20. JSTOR, www.jstor.org/stable/27746342.

Howat, John K., and Frederic Edwin Church. Frederic Church. Yale University Press, 2006.

Howat, John K. "Twilight in the Wilderness." American Paradise: The World of the Hudson River School. Metropolitan Museum of Art, New York 1987.

Howells, William Dean, and Paul R. Petrie. The Rise of Silas Lapham: Authoritative Text, Contexts, Criticism. W.W. Norton \& Company, Inc., 2018. 
Imbert, Patrick. "The Garden and its Multiple Contexts in Canada, the United States, and Latin America." Mosaic: A Journal for the Interdisciplinary Study of Literature. 38. 4, 2005, p. 51-65. Gale Academic OneFile, https://link-galecom.libproxy.uoregon.edu/apps/doc/A140086927/AONE?u=euge94201\&sid=AO NE\&xid=ecb93acd. Accessed 12 May 2020.

Jones, Ray, and Joseph M. Lubow. It Happened in Yosemite National Park: Remarkable Events That Shaped History. Globe Pequot Press, 2010.

Knight, Diana. "Review of Just Looking: Consumer Culture in Dreiser, Gissing and Zola by Rachel Bowlby," Poetics Today, 8. 1 1987, pp. 196-199. JSTOR, www.jstor.org/stable/1773013. Accessed 12 May 2020.

Marx, Leo. The Machine in the Garden. Oxford University Press, 2000.

Rose, Jane Atteridge. "A Bibliography of Fiction and Non-Fiction by Rebecca Harding Davis.” American Literary Realism, 1870-1910, 22. 3 1990, pp. 67-86. JSTOR, www.jstor.org/stable/27746417.

Stoner, Ruth. "Sexing the Narrator: Gender in Rebecca Harding Davis's 'Life in the Iron Mills." Scribbling Women \& the Short Story Form: Approaches by American \& British Women Writers, ed, Ellen Burton Harrington, Peter Lang, 2008, p. 28-36.

Thurston, George H. Pittsburgh as It Is: or, Facts and Figures, Exhibiting the Past and Present of Pittsburgh; Its Advantages, Resources, Manufactures, and Commerce. W.S. Haven, 1857.

West, Michael D. "Romantic Irony in the Short Fiction of Rebecca Harding Davis." American Literary Realism, 47. 3 2015, pp. 235-249. JSTOR, www.jstor.org/stable/10.5406/amerlitereal.47.3.0235. 